\title{
CORROSION OF THE REFRACTORY ZIRCONIA METERING NOZZLE DUE TO MOLTEN STEEL AND SLAG
}

\author{
KOROZIJA OGNJEODPORNE CIRKONSKE DOZIRNE ŠOBE \\ S STALJENIM JEKLOM IN ŽLINDRO
}

\author{
Klaudia Wiśniewska, Dominika Madej, Jacek Szczerba \\ AGH University of Science and Technology, Faculty of Materials Science and Ceramics, Department of Ceramics and Refractories, \\ Al. A. Mickiewicza 30, 30-059 Kraków, Poland \\ kwis@agh.edu.pl \\ Prejem rokopisa - received: 2014-08-08; sprejem za objavo - accepted for publication: 2015-03-03
}

doi: $10.17222 / \mathrm{mit} .2014 .188$

This paper presents a study on the phase composition and microstructure changes of a sintered Mg-stabilized zirconia metering nozzle exposed to the corrosive effect of the molten steel and slag in a tundish for continuous casting for $30 \mathrm{~h}$. A macroscopic observation of the corroded material showed cracks and two zones that were distinguished with respect to colour. An X-ray diffraction analysis showed that the dark layer was richer in stabilized $\mathrm{ZrO}_{2}$ than the light layer. After the corrosion test, the nozzle had higher contents of $\mathrm{MgO}, \mathrm{SiO}_{2}, \mathrm{CaO}, \mathrm{Al}_{2} \mathrm{O}_{3}$ and $\mathrm{Fe}_{2} \mathrm{O}_{3}$ than the reference sample as evidenced by an X-ray fluorescence analysis. Moreover, during the corrosion process, liquid steel and slag infiltrated the zirconia material, which was confirmed with a SEM investigation. Along the hot face of the metering nozzle, the grains of zirconium oxide recrystallized with a high-temperature structure of $\mathrm{ZrO}_{2}$ and dissolved $\mathrm{MgO}$ and $\mathrm{CaO}$ derived from the slag, stabilizing this phase.

Keywords: partially stabilized $\mathrm{ZrO}_{2}$, metering nozzle, corrosive effect of molten steel, refractories

Članek predstavlja študijo fazne sestave in mikrostrukturnih sprememb sintrane, z Mg stabilizirane cirkonske dozirne šobe, izpostavljene korozijskim vplivom staljenega jekla in žlindre po 30 urnem delovanju v vmesni ponovci pri postopku kontinuirnega litja. Makroskopsko opazovanje korodiranega materiala je pokazalo razpoke in dve področji, ki sta se razlikovali po barvi. Rentgenska difrakcijska analiza je pokazala, da je bilo temnejše področje bogatejše $\mathrm{s}$ stabiliziranim $\mathrm{ZrO}_{2}$, kot pa svetlejše področje. Rentgenska fluorescenčna analiza je pokazala, da ima šoba po korozijskem preizkusu, $\mathrm{v}$ primerjavi z referenčnim vzorcem, višjo vsebnost $\mathrm{MgO}, \mathrm{SiO}_{2}, \mathrm{CaO}, \mathrm{Al}_{2} \mathrm{O}_{3}$ in $\mathrm{Fe}_{2} \mathrm{O}_{3}$. Poleg tega sta, med procesom korozije, tekoče jeklo in žlindra prodirala $\mathrm{v}$ cirkonijev material, kar je bilo potrjeno s SEM preiskavo. Vzdolž vročega čela dozirne šobe so zrna cirkonijevega oksida rekristalizirala v visoko temperaturno strukturo $\mathrm{ZrO}_{2}$, raztopila $\mathrm{MgO}$ in $\mathrm{CaO}$, ki izvirata iz žlindre in stabilizirala to fazo.

Ključne besede: delno stabiliziran $\mathrm{ZrO}_{2}$, dozirna šoba, korozijski vpliv staljenega jekla, ognjevarna gradiva

\section{INTRODUCTION}

Partially stabilized $\mathrm{ZrO}_{2}$ (PSZ) materials are widely used as refractories owing to their high refractoriness, high corrosion resistance and good thermal-shock resistance. In the metal industry, the most popular are $\mathrm{Mg}$ and Ca-stabilized zirconia and Y-stabilized zirconia, applied in the production of thermal-barrier coatings. It is commonly known that during the corrosion process of PSZ due to molten steel and slag, a cubic or tetragonal phase is destabilized and transformed into monoclinic zirconia, related to the microcrack formation ${ }^{1}$. The destabilization process is associated with the reaction of $\mathrm{SiO}_{2}$ from slag with $\mathrm{CaO}$ and $\mathrm{MgO}$ from the zirconia material ${ }^{2,3}$. Zirconium oxide is used for metering nozzles in the continuous casting of steel ${ }^{2,4,5}$. A metering nozzle is mounted to the bottom of a tundish and used to control the flow of molten steel. The working temperature of a metering nozzle is up to $1600{ }^{\circ} \mathrm{C}$.

The main factors causing the damage of the metering nozzle are the erosion of the liquid flowing steel, the infiltration of the molten steel and slag into the refractory material, the slag composition and the rapid tem- perature changes ${ }^{2}$. The chemical composition of the slag is based on the $\mathrm{MgO}-\mathrm{CaO}-\mathrm{SiO}_{2}-\mathrm{Al}_{2} \mathrm{O}_{3}$ system, but the proportion between the components depends on the type of the produced steel.

In this paper the phase composition and microstructure changes of a sintered Mg-stabilized zirconia metering nozzle, exposed to the corrosive effect of the molten low-carbon steel and slag in a tundish for continuous casting for $30 \mathrm{~h}$ were studied.

\section{EXPERIMENTAL METHOD}

The procedure of this experiment included the following steps: preparing a sintered $\mathrm{Mg}$-stabilized zirconia metering nozzle under industrial conditions, a corrosion test in a tundish for continuous steel casting and a post-experiment study of the zirconia metering nozzle.

The metering nozzle was exposed to a corrosive environment for $30 \mathrm{~h}$. The factors influencing the corrosion of the nozzle were the molten steel and slag. After the corrosion test, the corroded nozzle (designated as $\mathrm{CN}$ ) 
was studied and compared with the reference sample (designated as RS), which was a zirconia metering nozzle before serving. For the XRF, XRD and SEM/EDS investigations, the samples were taken from the middle of the heights of the metering nozzles.

The X-ray fluorescence (XRF) method was used to determine the contents of oxides such as $\mathrm{MgO}, \mathrm{SiO}_{2}$, $\mathrm{CaO}, \mathrm{Al}_{2} \mathrm{O}_{3}$ and $\mathrm{Fe}_{2} \mathrm{O}_{3}$. An Axios $\mathrm{mAX}$ wavelength dispersive X-ray fluorescence spectrometer from PANalytical was used for this study. The crystalline phases were identified with $\mathrm{X}$-ray diffraction using $\mathrm{Cu}-K \alpha$ radiation on a FPM Seifert XRD7 diffractometer with the BraggBrentano geometry, while the quantitative composition was determined with the Rietveld method. The dark zone (designated as CN-D) and the light zone (designated as $\mathrm{CN}-\mathrm{L}$ ) of the corroded nozzle were examined separately. The microstructure was observed using a scanning electron microscope (SEM) coupled with an energy-dispersive X-ray system (EDS). The ultra-high-definition NOVA NANO SEM 200 was used for this purpose.

\section{RESULTS}

During a macroscopic observation of the corroded material, cracks and two zones were distinguished with respect to colour. The dark zone was strongly corroded due to molten steel and slag (the hot-zone refractory material) while the light zone remain unchanged. Figure 1 shows a photograph of the metering nozzle exposed to the corrosive effect of the molten steel.

The XRF analysis confirmed that the main component of the nozzle was zirconium oxide; the content of $\mathrm{ZrO}_{2}$ was about $90 \%$ in both $\mathrm{CN}$ and $\mathrm{RS}$ samples. Moreover, the XRF study revealed content changes in the oxides such as $\mathrm{MgO}, \mathrm{SiO}_{2}, \mathrm{CaO}, \mathrm{Al}_{2} \mathrm{O}_{3}$ and $\mathrm{Fe}_{2} \mathrm{O}_{3}$. After the corrosion test, sample $\mathrm{CN}$ had higher contents of these oxides, which is illustrated in Figure 2.

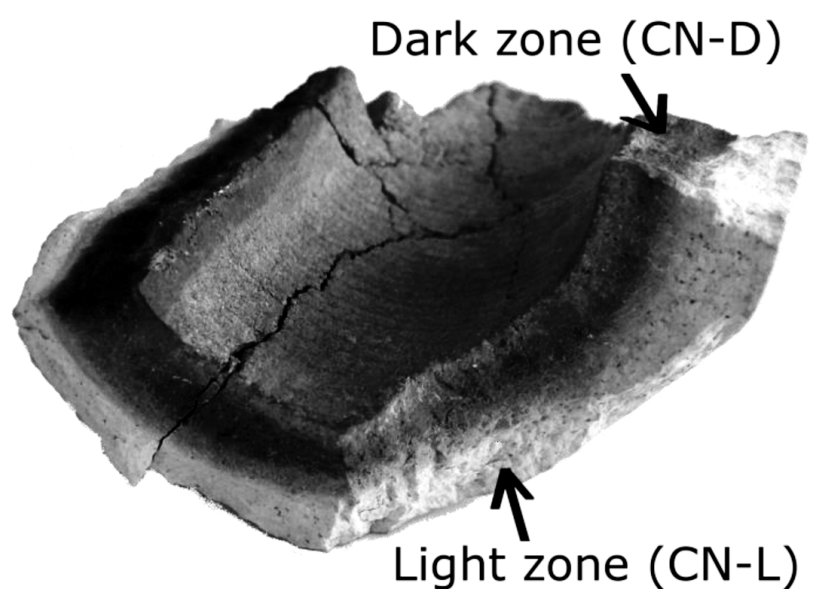

Figure 1: Refractory zirconia metering nozzle exposed to the corrosive effect of the molten steel and slag

Slika 1: Ognjevarna cirkonska dozirna šoba, izpostavljena korozijskemu vplivu staljenega jekla in žlindre

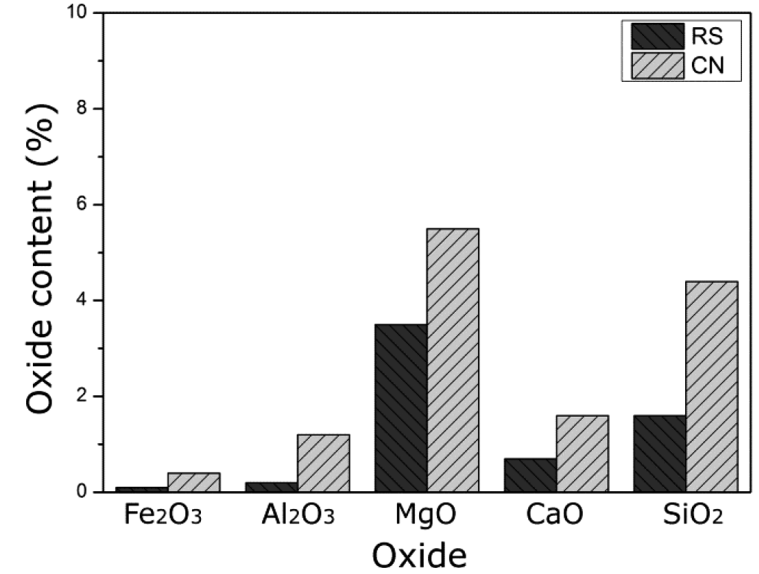

Figure 2: Contents of the secondary oxides in test samples RS and CN (XRF analysis)

Slika 2: Vsebnost sekundarnih oksidov v preizkusnih vzorcih RS in $\mathrm{CN}$ (XRF-analiza)

The XRD analysis with the Rietveld quantitativephase analysis showed that the dark layer (CN-D) was richer in the stabilized $\mathrm{ZrO}_{2}$ than the light layer $(\mathrm{CN}-\mathrm{L})$ or the RS sample. In the CN-D sample, the content of the stabilized zirconium oxide was $11.5 \%$, while in the

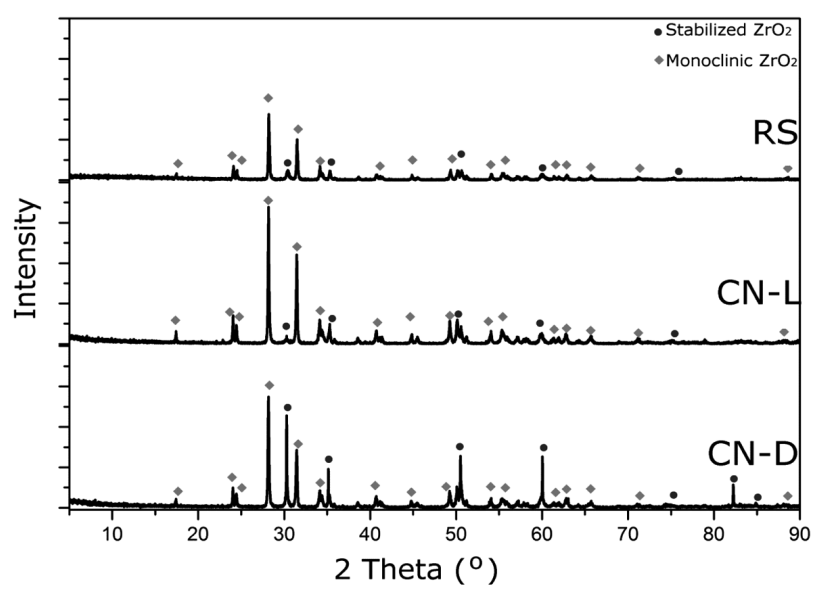

Figure 3: XRD patterns of test samples RS, CN-L and CN-D Slika 3: Rentgenogrami preizkusnih vzorcev RS, CN-L in CN-D

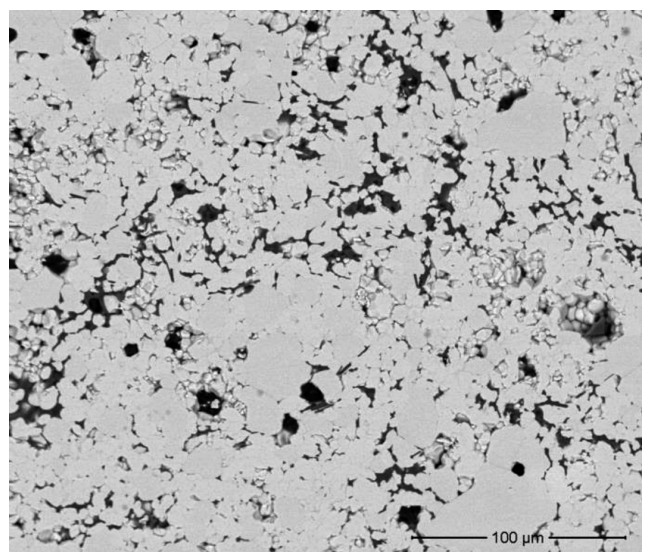

Figure 4: Microstructure of test sample RS

Slika 4: Mikrostruktura preizkusnega vzorca RS 


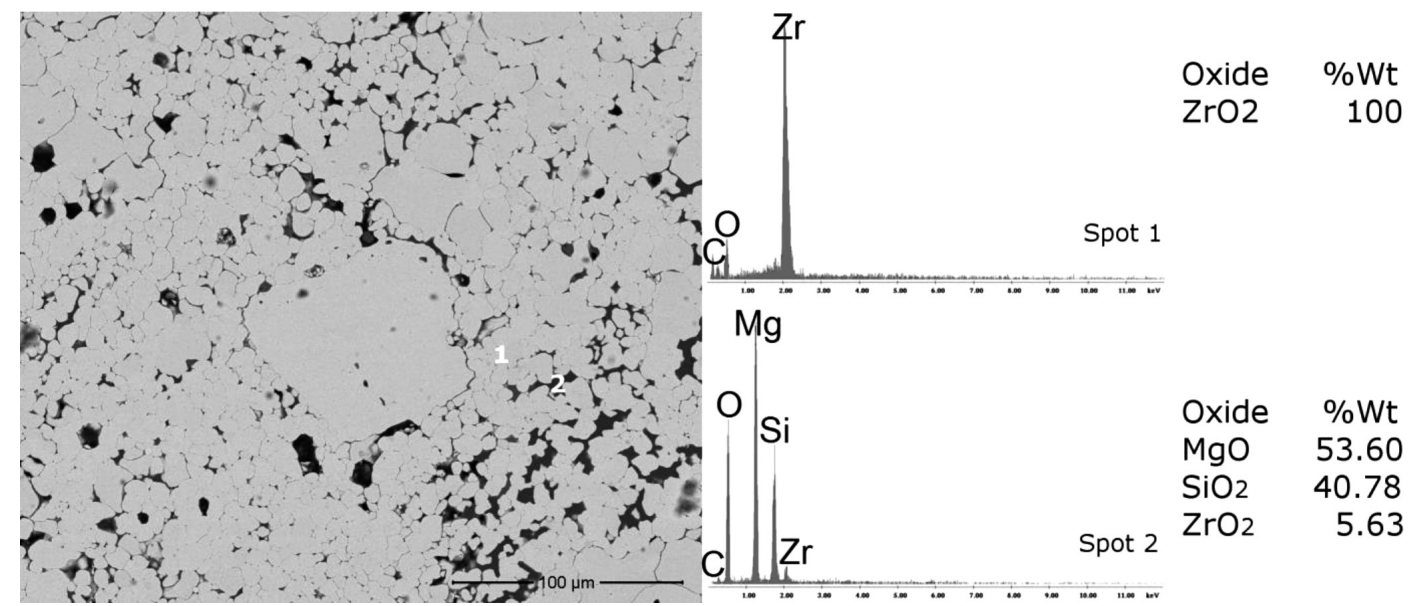

Figure 5: Microstructure of test sample CN-L obtained with the EDS analysis; Spot 1 - zirconium oxide, Spot 2 - forsterite Slika 5: Mikrostruktura preizkusnega vzorca CN-L z EDS-analizo; točka 1 - cirkonov oksid, točka 2 - forsterit

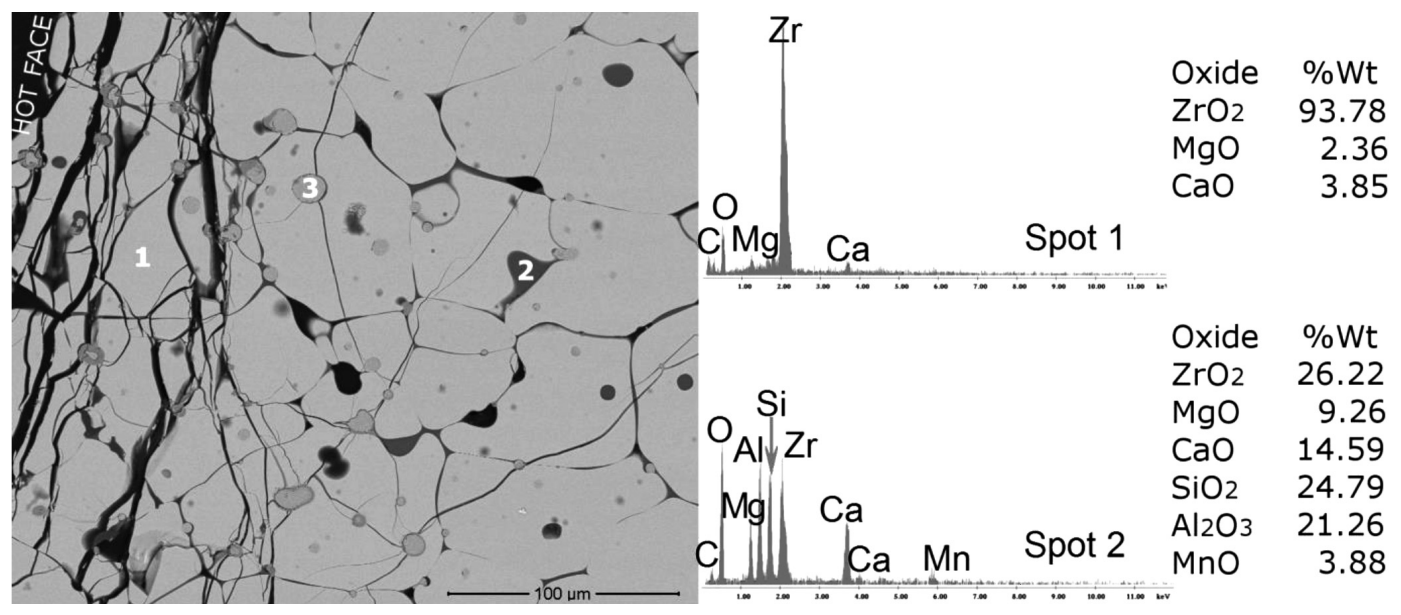

Figure 6: Microstructure of test sample CN-D obtained with the EDS analysis; Spot 1 - zirconium oxide, Spot 2 - slag, Spot 3 - iron Slika 6: Mikrostruktura preizkusnih vzorcev CN-D z EDS-analizo; točka 1 - cirkonov oksid, točka 2 - žlindra, točka 3 - železo

CN-L sample, it was $1 \%$ and in the RS sample, it was $3.3 \%$. The XRD results are shown in Figure 3.

Figures 4 to 6 show the microstructures of test samples RS, CN-L and CN-D, respectively. The microstructure of the CN-L sample is similar to the reference sample. The grains of zirconium oxide are surrounded by a silicate phase. The microstructure of sample CN-D shows micro-fracturing along the hot-face of the nozzle. The crystallites of zirconium oxide are bigger than in samples CD-L and RS.

\section{DISCUSSION}

In the reference sample, the main crystalline phases were monoclinic $\mathrm{ZrO}_{2}$ and $\mathrm{Mg}$-stabilized zirconium oxide, which were confirmed with the XRD analysis. The SEM/EDS investigation showed that the secondary phase was forsterite $\left(\mathrm{Mg}_{2} \mathrm{SiO}_{4}\right)$. However, the content of forsterite was too low to be detected on the XRD pattern. After the operation, there were two zones in the nozzle, a corroded and an uncorroded zone. The XRD analysis with the Rietveld method confirmed that test samples CN-L and RS were not significantly different in their phase composition. The biggest changes in the phase composition were found in the corroded zone (CN-D), where the content of stabilized zirconia was the highest.

The obtained results are not in agreement with the earlier results presented $\mathrm{in}^{2,3,5}$. The stabilization process of zirconium oxide can be explained with the dissolution of $\mathrm{MgO}$ and $\mathrm{CaO}$ derived from the slag in zirconia at a high temperature. The XRF and SEM/EDS investigations confirmed that, at the temperature of the corrosion test, the molten slag and steel penetrated the zirconia nozzle.

As can be seen in Figure 6, the microstructure of $\mathrm{CN}-\mathrm{D}$ was changed. The fine grains of $\mathrm{ZrO}_{2}$ recrystallized at the corrosion-test temperature, which was observed as an increase in their dimension. The hightemperature phase of zirconium oxide was stabilized due to $\mathrm{MgO}$ and $\mathrm{CaO}$, which dissolved in $\mathrm{ZrO}_{2}$. The micro-fractures along the hot face of the metering nozzle and the macroscopic cracks present in the corroded nozzle could be attributed to the rapid temperature changes during the corrosion test. 


\section{CONCLUSION}

The results of the corrosion of a refractory zirconia metering nozzle tested under industrial conditions are reported. During the service in a continuous-casting tundish, the molten steel and slag infiltrated the zirconia nozzle. A rapid change in the temperature had a significant influence on the formation of cracks and microfractures.

Along the hot face of the zirconia nozzle, the grains of $\mathrm{ZrO}_{2}$ recrystallized with a high-temperature structure. The oxides present in the slag dissolved in zirconia and stabilized the $\mathrm{ZrO}_{2}$ phase.

\section{Acknowledgments}

This work was supported by grant no. INNOTECHK2/IN2/16/181920/NCBR/13 of the National Centre for Research and Development.

\section{REFERENCES}

${ }^{1}$ A. Sibil, T. Douillard, C. Cayron, N. Godin, M. R'mili, G. Fantozzi, Microcracking of high zirconia refractories after $t \rightarrow m$ phase transition during cooling: An EBSD study, Journal of the European Ceramic Society, 31 (2011), 1525-1531, doi:10.1016/j.jeurceramsoc. 2011.02.033

${ }^{2}$ E. Volceanov, A. Abagiu, M. Becherescu, A. Volceanov, P. Nita, R. Trusca, F. Mihalache, Development of Zirconia Composite Ceramics and Study on Their Corrosion Resistance up to $1600{ }^{\circ} \mathrm{C}$, Key Engineering Materials, 264-268 (2004), 1739-1742, doi:10.4028/ www.scientific.net/KEM.264-268.1739

${ }^{3}$ Y. Hemberger, C. Berthold, K. G. Nickel, Wetting and Corrosion of Yttria Stabilized Zirconia by Molten Slags, Journal of the European Ceramic Society, 32 (2012), 2859-2866, doi:10.1016/j.jeurceramsoc. 2011.12.005

${ }^{4}$ A. H. Bui, S. C. Park, I. S. Chung, H. G. Lee, Dissolution Behavior of Zirconia Refractories During Continuous Casting of Steel, Metals and Materials International, 12 (2006) 5, 435-440, doi:10.1007/ BF03027711

${ }^{5}$ M. O. Suk, J. H. Park, Corrosion Behaviors of Zirconia Refractory by $\mathrm{CaO}-\mathrm{SiO}_{2}-\mathrm{MgO}-\mathrm{CaF}_{2} \mathrm{Slag}$, Journal of the American Ceramic Society, 92 (2009), 717-723, doi:10.1111/j.1551-2916.2008.02905.x 